\title{
KOMUNIKASI POLITIK KONTEMPORER INDONESIA
}

\author{
Samugyo Ibnu Redjo \\ e-mail: samugyo.ir@gmail.com
}

\begin{abstract}
ABSTRAK
Dipahami bahwa kekuasaan yang terpusat cenderung korup, begitu pula menyalahgunakan kewenangannya, baik hal itu dilakukan oleh individu maupun oleh kelompok elit penguasa, dan kondisi seperti ini menyebabkan ketidakberdayaan dan ketidakpercayaan warganegara terhadap pemerintahan. Untuk meminimalisir kondisi tersebut, salah satu yang harus dilakukan pemerintah adalah membangun komunikasi politik yang mengedepankan prioritas opini yang penting untuk dikembangkan. Hal ini juga menegaskan adanya keterwakilan rakyat atas masalahmasalah yang ia hadapi, sehingga muncul simpati publik terhadap kebijakan yang diambil pemerintah. Dalam artikel ini dibahas bagaimana kegagalan komukasi politik sering terjadi sehingga membuat hubungan antara yang-memerintah (pemerintah) dan yang-diperintah (masyarakat) menjadi tidak terjalin dengan baik, dan isu-isu apa saja yang seringkali mengemuka dalam wacana komunikasi politik kontemporer di Indonesia saat ini.
\end{abstract}

Kata Kunci: Komunikasi Politik Kontemporer, Pemerintahan, Isu Politik.

\section{ABSTRACT}

Understood that power tends to corrupt and abusing the authority, not only by individual but also by elite group ruler and of these condition has lead powerlessness and distrust the citizens to government. To minimize its situation, one of thing that must be doing by government is develop political communication which is forward of priority opinion that important to developed. This thing also confirms representation above the problems has faced. So that appears sympathize from public to government policy. This article will discussed about how political communication default often happen, so it is make the relation between government and public be coming unwell and what is the issues that always come up in contemporary political communication discourses in Indonesia nowadays.

Keywords: Contemporary Political Communication, Government, Political Issue. 


\section{Pendahuluan}

Komunikasi politik kontemporer di Indonesia tidak dapat dilepaskan dari komunikasi politik yang dikembangkan dalam kepolitikan global, karena keberadaan komunikasi politik ini ditentukan oleh tarikmenarik antara kepentingan global dan kepentingan nasional/lokal. Tarikan kepentingan tersebut lebih bernuansa kepentingan ekonomi dan kepentingan ideologi dunia dalam bentuk demokratisasi dan hak asasi manusia (HAM). Hal itu tidak dapat dihindarkan karena era global berarti politik global, ekonomi global, pasar global, dan lingkungan global. Oleh sebab itu, dalam menyelenggarakan komunikasi politik kontemporer di Indonesia, tidak terlepas dari kinerja politik Pemerintah dalam mengapresiasi kepentingan global untuk kepentingan nasional.

Hal ini penting dipersoalkan, karena dari beberapa orde pemerintahan yang ada di Indonesia komunikasi politik yang dipergunakan tidak menyebabkan surutnya praktekpraktek politik yang kurang demokratis, baik pada tataran pemerintah Pusat maupun pemerintah Daerah. Praktek-praktek politik seperti inilah yang kemudian memunculkan kesimpulan bahwa komunikasi politik kontemporer di Indonesia hanya bisa dipahami melalui oleh sekelompok kecil elit yang kemudian mengembangkan fenomena-fenomena politik yang tidak demokratis, tidak menghargai perbedaan, lebih mementingkan kelompok, dan kurang memperhatikan HAM. Fenomena tersebut sangat tampak tatkala tindakan-tindakan politik yang dilakukan oleh individu maupun kelompok berbeda dengan kehendak Pemerintah, maka tindakan tersebut dianggap sebagai melawan Pemerintah. Dan bagi individu maupun kelompok pelaku politik tersebut, tindakannya dianggap sebagai pembenaran (justification) dari ketidakdemokratisan kerja Pemerintah. Hal ini menunjukkan bahwa mekanisme musyawarah-mufakat baru sekedar slogan/lips service semata dan belum tertanam sebagai nilai-nilai yang mengikat tindakan-tindakan politik warganegara. Komunikasi politik kontemporer yang dikembangkan saat ini setidaknya dapat menangkal komunikasi politik satu arah yang selama ini dilakukan pemerintah yang cenderung sangat sentralistis, dimana Presiden memegang penuh seluruh kebijakan yang perlu dikomunikasikan. Hal ini berakibat pematangan politik tidak terjadi, di samping menyebabkan terjadinya political decay (pembusukan politik).

Dipahami bahwa kekuasaan yang terpusat cenderung korup dan menyalahgunakan kewenangan baik hal itu dilakukan oleh individu maupun oleh kelompok elit penguasa dan kondisi seperti ini menyebabkan ketidakberdayaan dan ketidakpercayaan warganegara terhadap Pemerintahan. Dan tatkala warganegara tidak berdaya dan tidak percaya pada 
Pemerintah, maka pada saat itu komunikasi politik yang dilakukan pemerintah perlu mengedepankan prioritas opini yang penting untuk dikembangkan. Pengembangan opini tentunya didasarkan pada keterwakilan rakyat atas masalah-masalah yang ia hadapi, sehingga muncul simpati publik terhadap kebijakan yang diambil pemerintah. Kemampuan mengemas opini publik yang kemudian dimatangkan dalam perdebatan publik, akan membawa pada suatu suasana politik yang dinamis. Suasana politik yang dinamis umumnya akan memunculkan keseimbangan kekuatan politik; akan tetapi jika hal itu tidak terjadi maka pada saat yang sama akan memunculkan kelompok-kelompok tandingan yang merupakan kekuatan politik terselubung yang mengapresiasi kepentingan-kepentingan politik tertentu dengan tujuan chaos bagi kekuasaan politik. Dan kejatuhan suatu rezim tinggal menunggu waktu. Hal inilah yang antara lain menjadi pemicu munculnya berbagai stigma politik dalam gerakan reformasi.

Komunikasi Politik pada tataran sistem politik yang sentralistis ${ }^{24}$, umumnya bersifat doktriner, yaitu, bahwa kebijakan publik yang disusun bukan untuk diperdebatkan pada tataran publik. Hal ini menyebabkan tertutupnya ruang publik untuk mewacanakannya, akibatnya seringkali muncul kekecewaan terhadap kebijakan yang diambil. Kekecewaan yang akumulatif akan menjadi pemicu bagi perubahan yang lebih besar. Hal ini sangat tampak pada proses reformasi di Indonesia, dimana paradigma pemerintahan republik bergeser menjadi model kerajaan. Indikasinya, Presiden bertindak sebagai raja yang menentukan seluruh kebijakan negara dengan tanpa kontrol yang ketat dari lembaga politik lain. Akibat yang paling dirasakan adalah terabaikannya hak-hak individu warganegara, di samping mekanisme demokrasi yang tidak berlangsung sebagaimana mestinya. Hal itu dapat dilihat pada dan sangat kentara pada masa pemerintahan Soekarno dengan model Demokrasi Terpimpin-nya dan pada masa pemerintahan Soeharto dengan model Demokrasi Pancasila-nya. Kedua model demokrasi tersebut pada prakteknya merupakan pemerintahan yang sentralistis ${ }^{25}$, dimana kekuasaan tertinggi berada di tangan presiden sebagai seorang "individu", bukan di tangan Konstituante atau Majelis Permusyawaratan Rakyat sebagai suatu lembaga negara.

24 Lihat Almond, Gabriel and James S. Colemann, 1960.

25 Ibid.

232 | CosmoGov, Vol.1 No.2, Oktober 2015 
Komunikasi politik yang gagal membangun opini publik tentang pemerintahannya tampak sekali pada berbagai pergolakan politik yang mengatasnamakan suku, agama, etnik, gap ekonomi, gap sosial, perbedaan politik, serta kepentingan politik yang mengatasnamakan Elit. Akibat ketidakmampuan membangun opini publik yang positif serta sikap dan perilaku elit politik yang memihak pada kehendak individu penguasa atau pada "kapitalis-kapitalis" semu yang dibesarkan pemerintah menyebabkan banyak rakyat lapisan bawah yang kehilangan hak-haknya, bahkan juga kehilangan nyawanya. Fenomena kegagalan pemerintah membangun opini publik bukan hanya pada tataran pemerintah Pusat akan tetapi juga pada tataran pemerintah Daerah. Ketakutan yang kumulatif diasosiasikan sebagai tekanan bagi pemerintah untuk mengubah prilaku politiknya, dalam kenyataannya tidak dipersepsi dalam komunikasi politik yang menyeimbangkan antara kehendak publik dan kehendak pemerintah. Dapat diduga bahwa ketidakseimbangan ini justru akan menyebabkan opini publik yang tidak sehat terhadap pemerintahannya. Konsekuensi inilah yang harus ditanggung rezim pemerintahan Presiden Soeharto pada saat terjadinya proses reformasi.
Fenomena komunikasi politik yang gagal membangun opini publik yang positif, menyebabkan berhentinya perkembangan budaya politik partisipatif $^{26}$ yang seharusnya ada pada setiap negara demokrasi. Sementara diketahui bahwa tidak ada satupun kekuatan yang bisa menghentikan informasi dan cuaca politik Indonesia tidak dapat memblokade informasi dari dunia luar. Akibatnya budaya politik partisipatif yang diharapkan pemerintah berubah arah menjadi kultur pembangkangan terhadap kebijakan pemerintah. Namun disayangkan bahwa kultur pembangkangan tidak terakomodasi dalam saluran-saluran politik yang tepat yang memungkinkan kompetisi politik secara sehat. Hal inilah yang menyebabkan munculnya oposisi jalanan, para avonturir politik, dan kelompok-kelompok masyarakat yang menjadi corong dari kekuatankekuatan politik yang menginginkan destabilisasi.

Fenomena kegagalan komunikasi politik pemerintah dalam membangun opini publik yang positif terhadap pemerintahan memang tidak dapat disalahkan seratus persen, karena komunikasi politik tidak dapat membangun budaya politik. Orientasi, sikap dan nilai politik umumnya terbentuk secara turun-temurun dan

26 Kajian mendalam tentang "budaya politik partisipatif di negara berkembang”, lihat Huntington, 1984. 
tersosialisasi melalui proses pendidikan politik. Oleh sebab itu jika pendidikan politik telah gagal membentuk budaya politik yang diinginkan, maka proses komunikasi politik juga akan mengalami kegagalan. Dalam negara yang bercirikan patrimonialisme, seperti Indonesia, peran pemerintah sangat besar dalam pendidikan politik. Oleh sebab itu, jika budaya politik yang tidak demokratis yang dikembangkan, maka dapat diduga bahwa tindakantindakan politik masyarakatpun akan juga tidak demokratis. Dan jika budaya korupsi yang dikembangkan, maka jangan disalahkan apabila bentuk negara berubah dari negara demokrasi ke negara kleptokrasi. Demikian juga permasalahan yang berkaitan dengan hukum dapat diatur dengan uang, uang menjadi penguasa politik, uang menjadi nyawa demokrasi, karena suara kebenaran dapat dibeli dengan uang. Dan ketidakadilan merupakan fenomena biasa karena "anggapan siapa yang punya uang, dia yang berkuasa". Kecenderungan inilah yang terjadi dan dipersepsi oleh mayoritas rakyat Indonesia tatkala proses reformasi berlangsung. Akan tetapi persepsi itupun belum banyak berubah tatkala reformasi telah kehilangan agenda, antara lain dapat diketahui dari persepsi rakyat tentang pemerintahan saat ini, yaitu pemerintahan mobokrasi, yaitu pemerintahan yang kebijakannya ditentukan oleh tekanan-tekanan gerombolan atau kelompok-kelompok di luar parlemen ataupun kabinet yang digerakkan dengan imbalan materi.

Pada kondisi seperti ini, maka membangun opini publik melalui komunikasi politik dengan dasar nilainilai demokratisasi merupakan hal yang harus dilakukan oleh pemerintah jika menginginkan suatu pemerintahan yang dapat bertahan lama. Tuntutan demokratisasi dalam kepolitikan sudah merupakan tuntutan global, dan umumnya tuntutan global akan menggunakan segala macam cara untuk dapat berhasil. Oleh sebab itulah, maka komunikasi politik kontemporer seyogyanya didasarkan pada asas demokrasi. ${ }^{27}$

\section{Komunikasi Politik Kontemporer Indonesia}

Isu keadilan, isu hukum, isu agama, isu kesukuan, isu rasial, isu kedaerahan, dan isu kesenjangan kemakmuran merupakan isu-isu aktual yang berkembang dalam kepolitikan di Indonesia selama ini. Dan hal ini

27 Lihat Raboy, Marc dan Peter A. Bruck (ed)., 1989. 
semakin menguat dewasa ini melalui berbagai kerusuhan di daerah. Isu-isu aktual tersebut sewaktu-waktu diperkirakan akan muncul dalam bentuk keberingasan dan kebrutalan sosial. Kasus Situbondo (1998) merupakan salah satu kasus dimana isu yang diangkat ke permukaan adalah isu agama, juga kasus Ambon (1999), Ternate (1999), dan Mataram (2000) dewasa ini berangkat dari kasus yang sama, terlepas dari permainan politik elit, tetapi yang jelas bahwa isu agama merupakan komoditas yang paling laku dijual dalam perdagangan politik. Demikian pula halnya kasus Sampang (2001) dan Tasikmalaya (1963 dan 2000), walaupun secara substansial lebih mengarah pada isu rasial dan isu keadilan. Hal yang sama terjadi di Pasuruan (2000) dan Pekalongan (2000), yang orientasinya adalah faktor keadilan antara pribumi dan non-pribumi yang umumnya merupakan sentimen-sentimen yang diperbesar oleh perilaku-perilaku aparatur pemerintah melalui tindakantindakan yang cenderung lebih mengedepankan tujuan daripada cara yang harus ditempuh. Akibatnya muncul sinyalemen bahwa dalam praktek-praktek keadilan baik yang menyangkut ijin mendirikan tempat peribadatan, ijin pembebasan tanah, ijin pelebaran jalan, ijin pembuatan tempat-tempat rekreasi (lapangan golf), maupun ijin untuk membuat perkebunan-perkebunan besar dan industri serta pabrik-pabrik, telah terjadi praktek-praktek kolusi antara pemerintah dan pengusaha. Fenomenafenomena tersebut berakumulasi dan berkembang dalam persepsi masyarakat di daerah. Dan akumulasi sentimen tersebut yang seringkali muncul dalam keberingasan dan kebrutalan sosial.

Lingkaran keberingasan dan kebrutalan sosial umumnya multi dimensi, artinya bahwa tindakantindakan yang dilakukan oleh masyarakat tersebut tidak hanya didasari oleh satu atau dua aspek pencetus tindakan keberingasan. Hal ini tampak dari tindakan keberingasan sosial terhadap kelompok non-pribumi (terutama Cina) yang menyebar hampir merata di seluruh propinsi. Di Jawa Barat lingkaran tersebut ditandai melalui sentimen agama, ekonomi, maupun keadilan. Dan dalam prakteknya, sentimen tersebut menjelma menjadi pengrusakkan dan pembakaran fasilitas-fasilitas milik nonpribumi. Lingkaran pengrusakkan dan pembakaran itu bersifat simultan. Dari catatan diketahui bahwa kerusuhan anti-Cina dimulai dari Cirebon tahun 1962, Bandung tahun 1973-1974, Tangerang dan Serang tahun 1980-an, dan Purwakarta tahun 1995. Hal yang sama juga terjadi pada propinsipropinsi lainnya di Jawa.

Apabila dilihat substansinya, maka isu/sentimen rasial tersebut umumnya lebih disebabkan karena adanya kesenjangan penikmatan kemakmuran, sebagai hasil dari adanya pembangunan. Bisa dipahami 
bahwa penikmatan kemakmuran oleh kelompok non-pribumi hampir merata di seluruh propinsi dan penikmatan tersebut di atas rata-rata penikmatan yang diterima oleh kelompok pribumi. Akibatnya adalah munculnya kecemburuan sosial, bahwa pembangunan untuk seluruh rakyat Indonesia ternyata lebih banyak dinikmati oleh kelompok-kelompok non-pribumi. Isu penikmatan ekonomi yang relatif di atas rata-rata ini, lebih mempercepat terjadinya kecemburuan rasial, karena umumnya non-pribumi beragama di luar agama mayoritas pribumi. Alhasil, isu rasial ini berubah menjadi isu agama dan sehubungan agama merupakan faktor yang dominan mampu mengubah emosi massa, maka isu agama ini yang sering dimunculkan dalam keberingasan-keberingasan sosial.

Isu keadilan menjadi isu lokal lebih disebabkan karena tindakantindakan arogan para pejabat di daerah. Arogansi ini antara lain tampak dari tindakan-tindakan pejabat di daerah, misalnya: tindakan Bupati Kabupaten Asahan (Sumatera Utara) dalam membangun jalan yang tidak dimusyawarahkan dengan penduduk, yang akibatnya terjadi tindakan-tindakan kekerasan yang dilakukan oleh masyarakat terhadap fasilitas-fasilitas milik pemerintah. Tindakan arogan yang menunjukkan sikap otoritarianisme tampak dari tindakan Walikotamadya Surabaya yang melecehkan profesi wartawan dan pernyataanpernyataan Gubernur Jawa Tengah yang cenderung memaksakan pikirannya pada pembangunan kantor dan rumah dinas Gubernur Jawa Tengah, juga keputusan Walikotamadya Ujung Pandang yang berakibat pada demonstrasi yang menewaskan mahasiswa. Sikap-sikap aparatur di atas, ditanggapi oleh masyarakat daerah dengan sikap takut, berpraduga (prejudice) dan bukan sikap toleran.

Sikap prejudice di atas, tampak dari persepsi masyarakat bahwa dalam praktek-praktek pembangunan telah terjadi kolusi antara penguasa dan pengusaha, yang umumnya menguntungkan salah satu pihak dan merugikan rakyat pada umumnya. Isu keadilan ini tampak dari isu mengenai tanah, dimana kepentingan umum dipropagandakan, sementara penikmatannya bersifat individual. Dalam konsep dan persepsi tersebut, rakyat merasa dirugikan, artinya bahwa hukum tidak melindungi mereka.

Pada isu kedaerahan, orientasi utamanya adalah pada penggantian pejabat-pejabat daerah. Dan momentum ini menjadi besar melalui campur tangan avonturir-avonturir politik yang mempertentangkan dan memilah birokrasi antara sipil-militer serta Pusat-Daerah. Dikotomi atau pemilahan ini menjadi aktual tatkala pemerintah campur-tangan terlalu besar dalam menempatkan pejabatpejabatnya di daerah. Isu kedaerahan lainnya adalah isu yang diangkat melalui sumber-sumber kharismatik daerah yang dipersonifikasikan pada 
diri seorang tokoh atau elit daerah. Dan personifikasi tokoh kharismatis akan mampu mempengaruhi massanya, antara lain dapat dilihat pada kasus Sampang, Situbondo, dan Nipah. Isu-isu kedaerahan tersebut akan berkorelasi pada perilaku politik massa.

Berdasarkan indikasi sejarah politik pemerintahan sentralistis, makna demokrasi serta isu-isu politik yang berkembang di atas, maka secara umum kekuatan politik kontemporer di Indonesia apapun nama dan sifat organisasinya akan bermain dan memanfaatkan isu-isu politik sebagai berikut: pertama, isu kesenjangan yang diindikasikan pada: Kesenjangan ekonomi kaya dan miskin; pengusaha dan buruh. Kesenjangan Pendidikan Kota dan Desa; Kesenjangan Pembangunan Jawa dan luar Jawa dan Kesenjangan Politik Elit-Massa. Kedua, isu demokratisasi dan HAM yang menyangkut kebebasan berpendapat, UU bidang politik, Pemerintahan, dan Perimbangan Keuangan Pusat dan Daerah serta pelanggaranpelanggaran HAM.

Ketiga, isu kemiskinan, buruh dan tani, pengangguran masyarakat terdidik serta ketergusuran masyarakat miskin kota atau pribumi yang dikalahkan. Keempat, isu kapitalisme konglomerasi non pribumi, nepotisme ekonomi partai politik, kapitalis semu anak pejabat, liberalisasi ekonomi yang meminggirkan produk dalam negeri serta monopoli ekonomi pada produk-produk pasar yang berkaitan dengan harkat hidup masyarakat banyak. Kelima, isu pemanfaatan profesionalisme, intelektual/cendekiawan; distribusi jabatan-jabatan politik dan jabatan karir; prilaku politik aparat yang menunjuk pada arogancy partai politik dan kesombongan penguasa. Keenam, isu transparansi kebijakan yang menunjuk kelompok yang dimenangkan dan kelompok yang dikalahkan. Ketujuh, isu-isu yang berkaitan dengan kesukuan, agama, ras, dan antar golongan.

Berkembangnya berbagai isu di atas, setidaknya menunjukkan bahwa komunikasi politik yang dilakukan oleh pemerintah dalam membangun opini publik telah gagal untuk menepis isu-isu negatif di atas. Akibat yang paling dirasakan dari kegagalan komunikasi politik yang dilakukan pemerintah, adalah terganggunya hubungan-hubungan sosial, politik, dan ekonomi antara rakyat. Dan dengan terganggunya hubunganhubungan tersebut, maka terganggu pula ikatan kebangsaan. Jika hal ini dibiarkan terus berlangsung, maka disintegrasi bangsa tinggal menunggu waktu. Dalam konteks ini, peran Komunikasi Politik Kontemporer Indonesia merupakan salah satu aspek untuk mengatasi kemungkinan terjadinya dis-integrasi tersebut melalui komunikasi diplomasi. 


\section{Penutup}

Dari kajian di atas, maka komunikasi politik yang perlu dilakukan adalah melakukan komunikasi secara spesifik/khusus dengan memilah isuisu tertentu, karena dasar dari berkembangnya isu-isu tersebut berbedabeda. Karena dasar yang berbeda itulah, maka kerja komunikasi politik relatif sulit, disamping kondisi politik yang berbeda antara satu wilayah dan wilayah lain.

Untuk itulah maka berbagai rekomendasi pewacanaan komunikasi politik yang perlu dilakukan. Pertama, dalam hal isu agama, maka komunikasi politik yang perlu dilakukan adalah tindakan-tindakan yang menunjukkan adanya keadilan hukum dan keadilan atas nilai-nilai yang hidup di masyarakat. Untuk kasus seperti Situbondo, Ambon, Mataram, dan Ternate maka tidak selayaknya apabila pemerintah menyerahkan kepada masyarakat untuk menyelesaikan masalahnya sendiri, karena justru fungsi Pemerintah adalah memoderatori konflik-konflik masyarakat. Semakin cepat Pemerintah menyelesaikan persoalan tersebut, maka semakin tertutup peluang elit politik yang bermain dengan mengatasnamakan kekuatan-kekuatan politik tertentu menjual agama untuk kepentingan sendiri. Kearifan dan keadilan serta pengayoman merupakan modal bagi Pemerintah untuk menyelesaikan masalah-masalah tersebut.
Kedua, dalam hal arogansi pemerintah, maka selayaknya pemerintah lebih menekankan pada pejabat yang bersangkutan untuk mencoba lebih bertindak sebagai pamong yang arif dan bijaksana, artinya bahwa kepamongan pejabat-pejabat tersebut harus didukung oleh tokoh-tokoh kharismatik di daerah tersebut serta oleh tokoh-tokoh agama yang mendukung. Kerja komunikasi politik pada isu ini adalah pada konteks internal pemerintahan, sehingga bukan lagi komunikasi persuasif ataupun diplomasi yang perlu dilakukan melainkan melakukan melalui koreksi internal.

Ketiga, isu keadilan, maka yang selayaknya dilakukan adalah membatasi sikap-sikap yang cenderung lebih menekankan pada pencapaian target dan bukan pada cara. Untuk itu selayaknya model tersebut diubah menjadi lebih mendahulukan cara untuk mencapai target yang telah ditentukan.

Keempat, dalam hal isu kedaerahan maka yang perlu dilakukan adalah bukan memadamkan kehendak Daerah, melainkan dikompilasikan dengan keinginan Pusat. Dengan demikian terjadi simbiosis antara kehendak Pusat dan kehendak rakyat di Daerah. Pemaksaan kehendak Pusat semata akan lebih memperuncing sentimen kedaerahan yang berdampak pada disintegrasi politik. Komunikasi politik diplomasi yang didasarkan demokratisasi menjadi pisau utama untuk memecahkan masalah-masalah ini. 
Keempat rekomendasi di atas, akan dapat efektif apabila komunikasi politik kontemporer juga merupakan koreksi terhadap berbagai kebijakankebijakan yang mendorong strukturstruktur di bawahnya untuk mampu melaksanakan fungsi-fungsi politiknya.

\section{Daftar Pustaka}

Almond, Gabriel and James S. Colemann, 1960. The Politics of the Developing Areas. New York: The Princenton University Press.

Almond, Gabriel and Sidney Verba, 1965. The Civic Culture. Boston: Litle Brown.

Dahl, Robert A., 1982. Analisa Politik Modern. Jakarta: PT Gramedia.

Huntington, Samuel P., 1984. No Easy Choice: Political Participation in Developing Countries. Cambridge Mass: Harvard University Press.
Kornhauser, William, 1973. The Politics of Mass Society. Glencoe III: The Free Press.

Lipset, Seymour M., 1959. Political Man: The Social Bases of Politics. New York: Dobleday.

Nimmo, Dann, 1993. Komunikasi Politik: Komunikator, Pesan, dan Media, Bandung: Remaja Karya.

Raboy, Marc dan Peter A Bruck (ed)., 1989. Communication for and against Democracy. New York: Black Rose Book.

Rauf, Maswadi, 1993. Komunikasi Politik: Masalah Sebuah Bidang Kajian dalam Ilmu Politik dalam Indonesia dan Komunikasi Politik., Maswadi Rauf dan Mappa Nasrun (ed), Jakarta: Gramedia. 